\title{
Availability and Uptake of Cadmium, Copper, and Zinc by Radish Plant Grown on Contaminated Soils as Affected by Compost Amendment
}

\author{
Mohamed L. Moharem, ${ }^{1}$ Hany A.S. Mitwally, ${ }^{1}$ Mohamed Rashad, ${ }^{2}$ Shalaby E.A., ${ }^{3}$
}

Ahmed Morsy ${ }^{3}$

\begin{abstract}
The study was conducted to elucidate the effect of three levels of compost amended soils $(0,3$, and $6 \%$, w/w) on $\mathrm{Cd}, \mathrm{Cu}$, and $\mathrm{Zn}$ extractability and uptake by radish plant (Raphanus sativus) grown in calcareous and sandy soils contaminated with $0,40,80$ or 160 mg metal $\mathrm{kg}^{-1}$ soil. DTPA extraction and greenhouse experiments were designed. The study revealed that the addition of compost treatments improved the plant biomass in both uncontaminated/contaminated two soils since the dry weight of shoots and roots for the two compost treatments was higher than that of the control ( 0 compost addition) even in high contamination level. Also, For $\mathrm{Cu}$ and $\mathrm{Zn}$, the plants cultivated in metals levels $\left(40-160 \mathrm{mg} \mathrm{kg}^{-1}\right)$ showed a significant increase in the dry weight in both radish shoots and roots grown in the both soils; whereas increase $\mathrm{Cd}$ levels from 40 to $160 \mathrm{mg} \mathrm{kg}^{-1}$ decreased the dry weight of both radish shoots and roots. DTPA extractable $\mathrm{Cd}$ and $\mathrm{Cu}$ in addition to their concentrations in radish shoots/roots grown in the soils were decreased as a result of compost amendments with more pronounced at high compost level; whereas the opposite results were obtained for $\mathrm{Zn}$. Good correlations were obtained in most cases between DTPA extractable metals and absorbed by radish plant indicated by correlation coefficients. These findings highlight the applicable of compost to ameliorate $\mathrm{Cd}$ and $\mathrm{Cu}$ risks in high contaminated soils.
\end{abstract} metals.

Keywords: DTPA, Plant uptake, Compost, Heavy

\section{INTRODUCTION}

The contamination of soils with heavy metals is now worldwide concerned due to their hazard to ecosystem including soil, water, plant, animal, and human life. The common international technologies of the remediation of the heavy metals contaminated sites are physical, chemical and biological techniques. The immobilization technique is commonly recognized for the in-situ remediation of heavy metals contaminated soils (Unite State Envi-ronmental Protection Agency (UA-EPA, 1999). Immobilization is the reduction of the solubility of heavy metals through chemical reactions (ion-

${ }^{1}$ Regional center for Food and Feed, Agricultural Research center,

Alexandria, Egypt

${ }^{2}$ Land and Water Technologies Department, Arid Lands

Cultivation Research Institute, City of Scientific Research and

Technological Applications (SRTA-City), New Borg Elarab,

Alexandria, Egypt

${ }^{3}$ Environmental Studies Department, Institute of Graduation Studies and Research (IGSR), Alexandria University, Egypt.

Received April14, 2016, Accepted May 8, 2016 exchange, adsorption, precipitation and complexation processes) making them less harmful or less mobile (Hashimoto et al., 2009 and Wang et al., 2009). The mostly applied amendments include clay material, cement, zeolites, and phosphates ( Finžgar et al., 2006).

Organic amendments such as mature compost, which contain a high proportion of humified organic matter (OM), can decrease the bioavailability of heavy metals in soil, thus permitting the re-establishment of vegetation on contaminated sites (Tordoff et al., 2000). This relies upon the ability of the $\mathrm{OM}$ to re-distribute heavy metals from soluble and exchangeable forms (extractable with solutions of neutral salts such as $\mathrm{CaCl}_{2}$ ) to fractions associated with $\mathrm{OM}$ or carbonates and the residual fraction (Narwal and Singh, 1998). Recently, Moharem (2016) examined the effect of 3 months incubation period of compost amended some Egyptian arid soils on mobility and availability of $\mathrm{Cd}$, $\mathrm{Cu}, \mathrm{Zn}$, and $\mathrm{Ni}$ using single extractants, and found that application of this material reduced the solubility of most studied metals. Great number of researchers who dealing with the issue of bioavailability are trying to estimate the available fraction by mimicking the plant uptake with extraction methods using neutral salts, weak acids and organic extractants. In general, single extractions by $\mathrm{CaCl}_{2}$, rhizosphere based method (RHIZO), or DTPA extractant, as the most appropriate methods correlated with plant uptake (Meers et al., 2007), mainly because these extractions express the concentrations of trace metals in soil solution and are able to release some weakly bound trace metals. Plant is basically doing the same. The trace metals in the soil solution are the most available fraction and, in addition to this readily available fraction, plant is capable of influencing the release of some weakly bound trace metals from the rhizosphere by excreting different exudates, mainly in the form of organic acids. However, there is no certainty that these methods will always give us the accurate estimations of bioavailabilty, as for bioavailability to be accurate it needs to take plant 
species or plant genotype, metal speciation and soil properties into account (Peijnenburg et al., 2007). So, based on the results obtained from short term heavy metals solubility/mobility in contaminated compost amended soils by means of single extractions (Moharem, 2016), in the current study we tock into account plant species coupled with DTPA extraction to: (1) demonstrate the effect of compost addition to contaminated calcareous and sandy soils on radish (Raphanus sativus) plant biomass, (2) elucidate the role of compost amended contaminated soils on bioavailability and radish plant uptake of $\mathrm{Cd}, \mathrm{Cu}$, and $\mathrm{Zn}$, and (3) correlate mathematically between data obtained from DTPA extraction and those from greenhouse experiments.

\section{MATERIALS AND METHODS}

\section{Soils}

Two different soil samples $(0-30 \mathrm{~cm})$ from two different locations were collected. The sandy soil was obtained from banana farm at $80 \mathrm{~km}$ Alexandria-Cairo

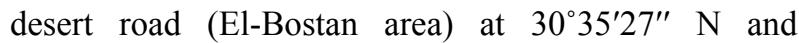
$30^{\circ} 11^{\prime} 7^{\prime \prime}$ E. The calcareous soil was from El- Nahda area $60 \mathrm{~km}$ west Alexandria city at $31^{\circ} 11^{\prime} 4^{\prime \prime} \mathrm{N}$ and $29^{\circ} 54^{\prime} 50^{\prime \prime}$ E. Soil samples were air-dried, ground, passed through $2 \mathrm{~mm}$ sieve and stored in plastic bags for later use. Soil $\mathrm{pH}$ was measured in 1:2.5 (soil:water) suspension and electric conductivity (EC) was measured in soil paste extract (Richards, 1954). The available Cd, $\mathrm{Cu}$, and $\mathrm{Zn}$ were extracted by DTPA (Lindsay et al., 1978) and measured by atomic absorption spectrophotometer (contrAA 300). Total metal concentrations were determined according to the method described by Ure (1995). Organic matter content was estimated by the method of Nelson and Sommer (1982), total carbonate equivalent was determined by the calcimiter method (Nelson, 1982) and cation exchange capacity was measured by the method of Rhoades (1982). Particle size analysis was determined by the hydrometer method (Hillel et al., 1972). Selected chemical and physical properties of the two soil samples are shown in Table 1.

\section{Compost}

Compost, having particle size less than $5 \mathrm{~mm}$, derived from organic waste material mainly agricultural solid waste (ASW) were obtained from Nahdat Misr Company for Environmental Services (formally was named Veolia) in Alexandria city. The analysis of the main properties of the compost was conducted as follows: $\mathrm{pH}$ was determined in aqueous solution $(1 / 5$, $\mathrm{v} / \mathrm{v})$. Total organic matter $(\mathrm{OM})$ was determined by Walkley and Black (Nelson and Sommers, 1982). Total $\mathrm{N}$ was measured by Kjeldahl digestion of samples and steam distillation (Keeney and Nelson, 1982).

Table 1. The main chemical and physical properties of the studied soils and compost

\begin{tabular}{|c|c|c|c|c|}
\hline Characteristics & units & Calcareous soil & Sandy soil & Compost \\
\hline $\mathrm{pH}^{\mathrm{a}}$ & & 7.9 & 8.0 & 7.9 \\
\hline EC & $\mathrm{dS} \mathrm{m}^{-1}$ & 4.54 & 1.12 & 4.7 \\
\hline Clay & $\%$ & 26.8 & 19.4 & - \\
\hline Silt & $\%$ & 6.4 & 13 & - \\
\hline Sand & $\%$ & 66.8 & 67.6 & - \\
\hline Texture & & sandy clay loam & sandy & - \\
\hline $\mathrm{OM}$ & $\%$ & 1.5 & 0.4 & 75.14 \\
\hline $\mathrm{CaCO}_{3}$ & $\%$ & 26 & 19 & - \\
\hline CEC & $\mathrm{cmol}_{\mathrm{c}} \mathrm{kg}^{-1}$ & 18 & 5 & 52 \\
\hline TOC & $\%$ & 0.87 & 0.23 & 43.70 \\
\hline $\mathrm{N}$ & $\%$ & - & - & 3.13 \\
\hline $\mathrm{C} / \mathrm{N}$ & & - & - & 14 \\
\hline Total metal & $\mathrm{mg} \mathrm{kg}^{-1}$ & & & \\
\hline $\mathrm{Cu}$ & & 33.48 & 20.58 & 210.25 \\
\hline $\mathrm{Cd}$ & & 0.01 & 0.05 & ND \\
\hline $\mathrm{Zn}$ & & 25.66 & 21.22 & 844.88 \\
\hline DTPA-extractable metal & $\mathrm{mg} \mathrm{kg}^{-1}$ & & & \\
\hline $\mathrm{Cu}$ & & 5.21 & 3.56 & - \\
\hline $\mathrm{Cd}$ & & ND & ND & - \\
\hline $\mathrm{Zn}$ & & 1.33 & 0.63 & - \\
\hline
\end{tabular}

a: measured in 1:2.5 (soil:water) suspension.

ND: not detected; -: not determined.

EC: Electrical conductivity; OM: organic matter; CEC: Cation exchange capacity; TOC: Total organic carbon; C/N: carbon: nitrogen ratio. 
Total concentrations of heavy metals in aqua regia digested extract (Esakku et al. 2005) were analyzed using atomic absorption spectrometry (contrAA300). The main chemical properties of the compost are shown in Table1

\section{Soil contamination:}

Soil samples (calcareous, sandy) of $1 / 2 \mathrm{~kg}$ were vigorously mixed with aqueous solution containing $\mathrm{Cd}\left(\mathrm{NO}_{3}\right)_{2}, \mathrm{Cu}\left(\mathrm{NO}_{3}\right)_{2}$ and $\mathrm{Zn}\left(\mathrm{NO}_{3}\right)_{2}$. The solution concentration and volume was adjusted to treat the soil with $0,40,80$ or $160 \mathrm{mg}$ metal $\mathrm{kg}^{-1}$ soil and to increase the soil moisture content to $10 \%$ in the calcareous and to $5 \%$ in the sandy soil. The contaminated soils were left for 3 days to reach equilibrium with the applied heavy metals.

\section{Compost soils amendment}

Each $500 \mathrm{~g}$ of the dry contaminated soil was intensely mixed in plastic bags with three rates of compost $(0,-3,6 \%, \mathrm{w} / \mathrm{w})$ representing (zero, low, high compost), respectively. The contaminated soil samples amended with compost were water saturated, air dried and thoroughly mixed.

\section{DTPA extraction}

$0.005 \mathrm{M}$ DTPA in $0.01 \mathrm{~N} \mathrm{CaCl}_{2}$ and $0.1 \mathrm{M}$ triethanolamine at $\mathrm{pH} 7.3$ was used for plant-available metals (Lindsay and Norvell, 1978). Concentrations of $\mathrm{Cd}, \mathrm{Cu}$, and $\mathrm{Pb}$ in DTPA extract for triplicate separated samples of each treatment were measured in the extract by the atomic absorption spectrophotometer (contrAA 300).

\section{Greenhouse experiment}

For soil samples contaminated with 4 rates of heavy metals and amended with three rates of compost, triplicate pots were filled with the mixed soil samples, and 15 radish seed (Raphanus sativus) were sown in each pot. After germination the seedlings were thinned to 5 plants per pot, and pots were irrigated with tap water by weight to $60 \%$ of water holding capacity. Every two days, pots were weighted and the moisture content was readjusted by adding tap water. Plant shoots and roots were harvested separately at 30 days after planting, washed and air dried in an oven at $72^{\circ} \mathrm{C}$ for 3 days, and ground after recording the dry weight, and kept for analysis. The experiment was set up for the 2 soils (calcareous and sandy), 3 heavy metals $(\mathrm{Cd}, \mathrm{Cu}$, and $\mathrm{Zn}), 4$ rates metals concentration $(0,40,80$ and 160 mg metal $\mathrm{kg}^{-1}$ soil), and 3 compost treatment (0, low, and high) in a simple randomization.

\section{RESULTS AND DISCUSSIONS}

\section{Effect of heavy metals and compost on radish growth}

Table 2 showed that the addition of the compost treatments improved the plant biomass in both uncontaminated/contaminated two soils since the dry weight of shoots and roots for the two compost treatments was higher than that of the control ( 0 compost addition). For instance, at $40 \mathrm{mg} \mathrm{kg}^{-1} \mathrm{Cd}, \mathrm{Cu}$, and $\mathrm{Zn}$ contaminated calcareous soil the shoot dry weight for high compost rate was 1.2, 1.7, and 1.3 times higher than that of the control, respectively; similarly, the shoots dry weight obtained from sandy soil was 1.2, 1.5, and 1.3 times higher than that of the control, respectively. Roots dry weight showed also similar trend of dry weight increase as a result of treated two soils with compost. Ye et al., (1999) found that dry weight yields of plant were higher in soils receiving compost amendment rather than control, indicating a better nutrient status in compost-amended soil. Also, the increased plant yield may be due to rhizosphere aggregate stability of compost that might favor the beneficial microbes that could have contributed to improved biomass (Caravaca et al., 2003).

The effect of contaminated soils with the three studied metals level on radish shoot/root dry weight was completely different among these metals. For $\mathrm{Cu}$ and $\mathrm{Zn}$ (Table 2), the plants cultivated in metals levels (40-160 $\mathrm{mg} \mathrm{kg}^{-1}$ ) showed a significant increase in the dry weight in both radish shoot and root with more pronounced in calcareous soil than sandy soil. In general, under lower application of these metals, improved root system helped the plants in better absorption of water and other nutrients dissolved in the soil and consequently improved the growth of different organs and the entire plant (Reichman, 2002). In contrary, Growth inhibition and reduction in biomass production are general responses of higher plants to heavy metal toxicity (Ouariti et al., 1997). The decrease in biomass in excess of these metals might be due to low protein formation, resulting in the inhibition of photosynthesis, as well as hampering carbohydrate translocation (Manivasagaperumal et al., 2011). However, the previous studies concerned with high levels of $\mathrm{Cu}$ and $\mathrm{Zn}$ which is far from these levels in the present investigation. Moreover, Plants treated with low level of copper (100-200 mg kg-1) and zinc (100-300 mg kg-1) showed a significant increase in the dry weight, while higher concentration of copper (300-600 mg kg-1) and zinc (400- $600 \mathrm{mg} \mathrm{kg}^{-1}$ ) showed a gradual decline in the dry weight that were obtained by several authors in a number of plants including radish (Dube et al., 2003). 
Table 2. Shoots and roots dry weight of radish plants grown in calcareous and sandy soils contaminated with different levels of heavy metals and amended with different rates of compost

\begin{tabular}{|c|c|c|c|c|c|c|c|c|c|c|c|c|}
\hline \multirow{4}{*}{$\begin{array}{c}\text { Compost } \\
\text { rate }\end{array}$} & \multicolumn{12}{|c|}{ Dry weight of radish plants (g) } \\
\hline & \multicolumn{6}{|c|}{ Calcareous soil } & \multicolumn{6}{|c|}{ Sandy soil } \\
\hline & \multicolumn{2}{|c|}{$\underline{\underline{C d}}$} & \multicolumn{2}{|c|}{$\underline{\mathrm{Cu}}$} & \multicolumn{2}{|c|}{$\underline{\underline{Z n}}$} & \multicolumn{2}{|c|}{$\underline{\mathbf{C d}}$} & \multicolumn{2}{|c|}{$\underline{\mathrm{Cu}}$} & \multicolumn{2}{|c|}{$\underline{\underline{Z n}}$} \\
\hline & Sh. & Ro. & Sh. & Ro. & Sh. & Ro. & Sh. & Ro. & Sh. & Ro. & Sh. & Ro. \\
\hline & \multicolumn{12}{|c|}{0 mg metal $\mathrm{Kg}^{-1}$ soil } \\
\hline Zero & $0.59 \mathrm{c}$ & $0.25 \mathrm{c}$ & $0.59 \mathrm{c}$ & $0.25 \mathrm{c}$ & $0.59 \mathrm{c}$ & $0.25 \mathrm{c}$ & $0.55 \mathrm{c}$ & $0.22 \mathrm{~b}$ & $0.55 \mathrm{c}$ & $0.22 \mathrm{~b}$ & $0.55 \mathrm{c}$ & $0.22 \mathrm{~b}$ \\
\hline Low & $0.82 \mathrm{~b}$ & $0.37 \mathrm{~b}$ & $0.82 \mathrm{~b}$ & $0.37 \mathrm{~b}$ & $0.82 \mathrm{~b}$ & $0.37 \mathrm{~b}$ & $0.74 \mathrm{~b}$ & $0.29 \mathrm{~b}$ & $0.74 \mathrm{~b}$ & $0.29 \mathrm{~b}$ & $0.74 \mathrm{~b}$ & $0.29 \mathrm{~b}$ \\
\hline \multirow[t]{2}{*}{ High } & $1.43 \mathrm{a}$ & $0.59 \mathrm{a}$ & $1.43 \mathrm{a}$ & $0.59 \mathrm{a}$ & $1.43 \mathrm{a}$ & $0.59 \mathrm{a}$ & $1.31 \mathrm{a}$ & $0.47 \mathrm{a}$ & $1.31 \mathrm{a}$ & $0.47 \mathrm{a}$ & $1.31 \mathrm{a}$ & $0.47 \mathrm{a}$ \\
\hline & \multicolumn{12}{|c|}{$40 \mathrm{mg}$ metal $\mathrm{Kg}^{-1}$ soil } \\
\hline Zero & $0.57 \mathrm{c}$ & $0.21 \mathrm{c}$ & $0.62 \mathrm{c}$ & $0.34 \mathrm{c}$ & $0.67 \mathrm{c}$ & $0.36 \mathrm{c}$ & $0.51 \mathrm{c}$ & $0.18 \mathrm{~b}$ & $0.59 \mathrm{c}$ & $0.32 \mathrm{~b}$ & $0.64 \mathrm{c}$ & $0.35 b$ \\
\hline Low & $0.77 \mathrm{~b}$ & $0.32 \mathrm{~b}$ & $0.97 \mathrm{~b}$ & $0.48 \mathrm{~b}$ & $0.92 b$ & $0.51 \mathrm{~b}$ & $0.65 \mathrm{~b}$ & $0.22 b$ & $0.92 b$ & $0.38 \mathrm{~b}$ & $0.83 b$ & $0.41 \mathrm{~b}$ \\
\hline \multirow[t]{2}{*}{ High } & $1.25 \mathrm{a}$ & $0.51 \mathrm{a}$ & $1.66 \mathrm{a}$ & $0.65 \mathrm{a}$ & $1.51 \mathrm{a}$ & $0.76 \mathrm{a}$ & $1.10 \mathrm{a}$ & $0.39 \mathrm{a}$ & $1.50 \mathrm{a}$ & $0.62 \mathrm{a}$ & $1.44 \mathrm{a}$ & $0.69 \mathrm{a}$ \\
\hline & \multicolumn{12}{|c|}{$80 \mathrm{mg}$ metal $\mathrm{Kg}^{-1}$ soil } \\
\hline Zero & $0.45 \mathrm{c}$ & $0.18 \mathrm{c}$ & $0.76 \mathrm{c}$ & $0.43 \mathrm{c}$ & $0.78 \mathrm{c}$ & $0.40 \mathrm{c}$ & $0.40 \mathrm{c}$ & $0.15 b$ & $0.66 \mathrm{c}$ & $0.37 \mathrm{~b}$ & $0.74 \mathrm{c}$ & $0.38 \mathrm{c}$ \\
\hline Low & $0.71 \mathrm{~b}$ & $0.27 \mathrm{~b}$ & $1.21 \mathrm{~b}$ & $0.56 \mathrm{~b}$ & $1.01 \mathrm{~b}$ & $0.56 \mathrm{~b}$ & $0.57 \mathrm{~b}$ & $0.18 \mathrm{~b}$ & $1.15 \mathrm{~b}$ & $0.43 b$ & $0.89 \mathrm{~b}$ & $0.49 \mathrm{~b}$ \\
\hline \multirow[t]{2}{*}{ High } & $1.10 \mathrm{a}$ & $0.40 \mathrm{a}$ & $1.70 \mathrm{a}$ & $0.74 \mathrm{a}$ & $1.63 \mathrm{a}$ & $0.81 \mathrm{a}$ & $0.98 \mathrm{a}$ & $0.29 \mathrm{a}$ & $1.62 \mathrm{a}$ & $0.67 \mathrm{a}$ & $1.55 \mathrm{a}$ & $0.73 \mathrm{a}$ \\
\hline & \multicolumn{12}{|c|}{$160 \mathrm{mg}$ metal $\mathrm{Kg}^{-1}$ soil } \\
\hline Zero & $0.42 \mathrm{c}$ & $0.17 \mathrm{~b}$ & $0.82 \mathrm{c}$ & $0.53 \mathrm{c}$ & $0.83 \mathrm{c}$ & $0.52 b$ & $0.36 \mathrm{c}$ & $0.12 \mathrm{~b}$ & $0.76 \mathrm{c}$ & $0.50 \mathrm{~b}$ & $0.81 \mathrm{c}$ & $0.47 \mathrm{c}$ \\
\hline Low & $0.61 \mathrm{~b}$ & $0.19 \mathrm{~b}$ & $1.49 \mathrm{~b}$ & $0.57 \mathrm{~b}$ & $1.23 \mathrm{~b}$ & $0.59 \mathrm{~b}$ & $0.54 \mathrm{~b}$ & $0.13 b$ & $1.28 \mathrm{~b}$ & $0.53 b$ & $1.09 \mathrm{~b}$ & $0.56 \mathrm{~b}$ \\
\hline High & $0.93 \mathrm{a}$ & $0.29 \mathrm{a}$ & $1.83 \mathrm{a}$ & $0.82 \mathrm{a}$ & $1.77 \mathrm{a}$ & $0.83 \mathrm{a}$ & $0.80 \mathrm{a}$ & $0.19 \mathrm{a}$ & $1.69 \mathrm{a}$ & $0.70 \mathrm{a}$ & $1.61 \mathrm{a}$ & $0.79 a$ \\
\hline
\end{tabular}

Thus from discussions above, it is not surprising for the increase of radish biomass as a result of adding $\mathrm{Cu}$ or $\mathrm{Zn}$ up to $160 \mathrm{mg} \mathrm{Kg}^{-1}$ in the current study.

In contrast to $\mathrm{Cu}$ and $\mathrm{Zn}$, increasing $\mathrm{Cd}$ concentration in both soils from 40 to $160 \mathrm{mg} \mathrm{kg}^{-1}$ soil either in the presence or absence of compost amendments significantly decreased plants dry weight. The decrease in radish dry weight was more pronounced in sandy soil than in calcareous soil. The bioavailability of $\mathrm{Cd}$ in sandy soil that has low organic matter, total carbonate, and CEC (Table 1) is expected to be higher than in the other soil rich in these previous parameters. In addition, Tables 3 and 4 show the tolerance index of radish shoots and roots grown in the studied soils- that were calculated as the ratio of shoot or root dry weight at Cd supply to that of control. In general, cadmium affected roots more than shoots in all cases leading to a lower tolerance index for root. This phenomenon can be attributed to the fact that roots are the first organs receiving cadmium ions in soils via apoplastic transport, resulting in a higher $\mathrm{Cd}$ accumulation there (Drażkiewicz et al., 2003).

\section{DTPA extractable metals}

Fig. 1 showed that in sandy soil; in the control $(0$, compost) and compost amended contaminated soils, $\mathrm{Cd}$,
$\mathrm{Cu}$, and $\mathrm{Zn}$ concentration in DTPA extracts were lower in calcareous soil than that of sandy soil suggesting that heavy metals in calcareous soil was less extractable and probably less bioavailable corresponding with the data obtained from the dry weight experiments (Table 2). The relatively low values of DTPA extractable metals from calcareous soil may be referred to higher organic matter, calcium carbonate, cation exchange capacity values of calcareous soil whereas the sandy soil shows the lowest values of these properties (Table 1). Many studies demonstrated the high affinity of organic matter, clay minerals, and $\mathrm{CaCO}_{3}$ for $\mathrm{Cu}$ (Karlsson et al., 2006). The high contents of $\mathrm{CaCO}_{3}$ in calcareous soil could be responsible for the high $\mathrm{Cu}$ sorption capacity in this soil. Ponizovsky et al. (2007) studied the mechanism of $\mathrm{Cu}$ retention in calcareous soils and suggested surface precipitation of $\mathrm{CuCO}_{3}$ as the main mechanism of $\mathrm{Cu}$ retention. Also the high affinity of $\mathrm{Cd}$ towards $\mathrm{CaCO}_{3}$ could be the reason for the low extractability of $\mathrm{Cd}$ in calcareous soil. Basta et al. (2001) found that $\mathrm{Cd}$ carbonate-bound fraction represented the highest value among the different fractions of extracted Cd. Dahiya et al. (2005) found that the cation exchange capacity, organic matter, $\mathrm{pH}$ and clay content were the main contributors to $\mathrm{Zn}$ sorption in soils. Mcbride (1994) also demonstrated that 
Zinc sorption by carbonates or precipitation of zinc hydroxide or carbonates may be partly responsible for the zinc unavailability in calcareous soils. These findings are in agreement with the results obtained from the current study regarding the low extractability of $\mathrm{Zn}$ in calcareous soil than in sandy soil.

When both soils were mixed with compost, as seen in Fig. 1, significant reduction in DTPA extractable Cd and $\mathrm{Cu}$ was noticed at different levels of added metals comparing with control treatment $(0$, compost), and this decrease was more pronounced in high compost amendment suggested that more sorption sites will be added on the soil surface as a result of compost addition. In contrast to both metals, DTPA extractable $\mathrm{Zn}$ seemed to be higher in compost amendment rather than control treatment. The non effectiveness of compost on $\mathrm{Zn}$ as a sportive material as in case of $\mathrm{Cd}$ and $\mathrm{Cu}$ may be related to the fact that $\mathrm{Zn}$ is a rather mobile element and easily out-competed by other cations (e.g. $\mathrm{Pb}, \mathrm{Cu}$ ) for adsorption sites (Cao et al., 2004). The current results were in agreement with Sanchez et al. (2004) who observed that the application of different organic mixtures to soil considerably increased the fraction of available $\mathrm{Zn}$. Addition of high compost rate strongly decreased $\mathrm{Cd}$ concentration of DTPA extracted in calcareous soil treated with $80 \mathrm{mg}$ $\mathrm{kg}^{-1}$ soil from 38.46 to $25.78 \mathrm{mg} \mathrm{kg}$ whereas the decrease in sandy soil amended with $80 \mathrm{mg} \mathrm{kg}^{-1}$ soil was from 45.24 to $31.25 \mathrm{mg} \mathrm{kg}^{-1}$. For Cu, DTPA extract of the two soils significantly decreased from 29.70 to $18.63 \mathrm{mg} \mathrm{kg}^{-1}$ and from 37.84 to $25.87 \mathrm{mg} \mathrm{kg}^{-1}$ for calcareous and sandy soils, respectively as a result of application high compost rate to contaminated soils at level of $40 \mathrm{mg} \mathrm{Cu} \mathrm{kg}^{-1}$ soil. DTPA extractable $\mathrm{Zn}$ in 80 $\mathrm{mg} \mathrm{kg}^{-1}$ calcareous soil increased from 34.49 to 40.16 $\mathrm{mg} \mathrm{kg}^{-1}$ whereas $\mathrm{Zn}$ concentration in DTPA extract of $40 \mathrm{mg} \mathrm{kg}^{-1}$ sandy soil increased from 30.45 to $33.92 \mathrm{mg}$ $\mathrm{kg}^{-1}$ as a result of high rate compost application for both soils. It can be deducted from the results above that $\mathrm{Cd}$ and $\mathrm{Cu}$ strongly retained in soil matrix following compost amendments suggested high affinity of both metals for compost rendering both metals in a less extractable form. The contrast results obtained in $\mathrm{Zn}$ indicated low ability of $\mathrm{Zn}$ towards compost materials. It is well known the ability of organic matter to bind metals, reducing their bioavailability and subsequently allowing vegetation to become established (Bohn et al., 1985). However, Some forms of unstabilized organic matter such as manure or biosolids may increase metal mobility due to their high DOM content that can complex metals and facilitate their movement through soil (Almas et al., 1999). In contrast, composting stabilizes organic wastes and reduces their DOM content and the potential for metal leaching (Van
Herwijnen et al., 2007). Stabilized organic matter has been shown to reduce available $\mathrm{Cu}$ and increase the organically bound fraction (Perez-de-Mora et al., 2007). Thus $\mathrm{Cu}$ that known to form stable complexes with dissolved organic carbon (Wu et al., 1999) causing increase of metal mobility and bioavailability especially in alkaline soils (Moharem, 2008), can be strongly diminished as a results of organic residuals composting process. For Cd, Kaschl et al. (2002) demonstrated a tendency of $\mathrm{Cd}$ to preferably associate with larger, humified, and less soluble organic materials predicting a high ability of $\mathrm{Cd}$ towards compost materials as obtained in the current study. Zinc is readily adsorbed by clay minerals, carbonates, or hydrous oxides. Kuo et al. (1983) and Tessier et al. (1980) found that the greatest percent of the total $\mathrm{Zn}$ in polluted soils and sediments was associated with $\mathrm{Fe}$ and $\mathrm{Mn}$ oxides. Other investigators also reported the dominance of the Fe and Mn oxide-bound Zn (Ramos et al., 1994; and Ahumada et al., 1999). On the other hand, Murthyet al. (1987) demonstrated that $\mathrm{Zn}$ in soil is held by weak organic bonding. Thus in the current study, it has been suggested that soil compost addition may limit the ability of soil components to retain $\mathrm{Zn}$ by covering the more favorable sites (clay minerals, carbonates, or hydrous oxides) by less favorable sites (organic matter of compost) causing more $\mathrm{Zn}$ extractability. In common, these findings indicate the importance of compost amendment via reducing the bioavailability of $\mathrm{Cu}$ and Cd.

\section{Heavy metals uptake by radish plants}

For control ( 0 , compost) and compost amended contaminated soils, $\mathrm{Cd}, \mathrm{Cu}$, and $\mathrm{Zn}$ concentration in radish shoots or roots dramatically increased as a results of metal added from 40 to $160 \mathrm{mg} \mathrm{kg}^{-1}$ (Figures 2 and $3)$. In general, metal added to soil was plotted versus shoots or roots metal concentration, and linear relationships were obtained for $\mathrm{Cd}, \mathrm{Cu}$, and $\mathrm{Zn}$ and two soils indicated by high coefficients of determinations $\left(\mathrm{R}^{2}\right)$ ranging from 0.86 to 0.99 (data shown in Fig. 4 as example for radish shoots in calcareous soil). Wang et al. (2003) concluded that the concentration of heavy metal in plants could be used as indicator to metal contamination status of the soil and revealed abilities of various plant species to take up and accumulate metals from polluted soils. In common, heavy metals concentrations in radish tissues was more pronounced in sandy soil than in calcareous soil. Cd concentration in radish shoot and root grown in sandy control soil and contaminated with $40 \mathrm{mg} \mathrm{kg}^{-1}$ soil was 2 and 7 times higher than corresponding radish in calcareous soil, respectively; while $\mathrm{Cu}$ at $80 \mathrm{mg} \mathrm{kg}^{-1}$ soil, radish shoot and root grown in sandy control soil was 2.2 and 12.4 times higher than that in calcareous soil, respectively; 
whereas $\mathrm{Zn}$ contaminated soils at $160 \mathrm{mg} \mathrm{kg}^{-1}$, radish shoot and root grown in sandy control soil was 1.7 and 2.2 times higher than that in calcareous soil, respectively. Furthermore in control amended contaminated soils, $\mathrm{Cd}$ and $\mathrm{Cu}$ concentration in roots where much higher than those in shoots as seen in Figures 2 and 3. Other investigations (Florijin et al., 1993 and Ren et al., 2006) also demonstrated that heavy metal concentrations in roots were much higher than those in shoots. The remaining of heavy metals in roots and transport of small amount to shoots has been considered as defense mechanism of plants for heavy metal toxicity by immobilization of heavy metal in root cell wall (Rauser, 1986). However, in the current study $\mathrm{Zn}$ concentration in shoots were much higher than those in roots indicating the high transport of $\mathrm{Zn}$ into radish tissues.

The addition of compost to both soils dramatically affected metals concentrations in shoots and roots of radish plants (Figures 2, 3 as example). The $\mathrm{Cd}$ and $\mathrm{Cu}$ concentrations in shoots and roots were decreased as results of compost addition with more obvious in high amendment rate while $\mathrm{Zn}$ concentration in shoot and root was increased as the increase of compost rate.

Table 3. Cadmium tolerance index of shoots and roots radish plant growing in calcareous soil as exposed to different $C d$ concentrations

\begin{tabular}{|c|c|c|c|c|c|}
\hline \multirow[b]{2}{*}{ Compost } & \multirow{2}{*}{$\begin{array}{l}\text { Cd concentration } \\
\left(\mathrm{mg} \cdot \mathrm{kg}^{-1}\right)\end{array}$} & \multicolumn{2}{|r|}{ Shoot } & \multicolumn{2}{|r|}{ Root } \\
\hline & & $\begin{array}{l}\text { Dry weight } \\
\left(\text { g.plant }{ }^{-1}\right)\end{array}$ & $\begin{array}{c}\text { Cd tolerance index } \\
(\%)\end{array}$ & $\begin{array}{l}\text { Dry weight } \\
\left.\text { (g.plant }^{-1}\right)\end{array}$ & $\begin{array}{c}\text { Cd tolerance index } \\
(\%)\end{array}$ \\
\hline \multirow{4}{*}{ Zero } & 0 (control) & $0.59 \mathrm{a}$ & 100 & $0.25 \mathrm{a}$ & 100 \\
\hline & 40 & $0.57 \mathrm{~b}$ & 96.6 & $0.21 \mathrm{a}$ & 84.0 \\
\hline & 80 & $0.45 \mathrm{c}$ & 76.3 & $0.18 \mathrm{ab}$ & 72.0 \\
\hline & 160 & $0.42 \mathrm{c}$ & 71.2 & $0.17 \mathrm{ab}$ & 68.0 \\
\hline \multirow{4}{*}{ Low } & 0 (control) & $0.82 \mathrm{a}$ & 100 & $0.37 \mathrm{a}$ & 100 \\
\hline & 40 & $0.77 \mathrm{~b}$ & 93.9 & $0.32 \mathrm{a}$ & 86.5 \\
\hline & 80 & $0.71 b$ & 86.6 & $0.27 \mathrm{~b}$ & 73.0 \\
\hline & 160 & $0.61 \mathrm{c}$ & 74.4 & $0.19 \mathrm{c}$ & 51.4 \\
\hline \multirow{4}{*}{ High } & 0 (control) & $1.43 \mathrm{a}$ & 100 & $0.59 \mathrm{a}$ & 100 \\
\hline & 40 & $1.25 \mathrm{~b}$ & 87.4 & $0.51 \mathrm{ab}$ & 86.4 \\
\hline & 80 & $1.10 \mathrm{~b}$ & 76.9 & $0.40 \mathrm{ab}$ & 67.8 \\
\hline & 160 & $0.93 \mathrm{c}$ & 65.0 & $0.29 \mathrm{~b}$ & 49.1 \\
\hline
\end{tabular}

Cadmium tolerance index was calculated as the ratio of shoot or root dry weight at $\mathrm{Cd}$ supply to that of control.

$\mathrm{p}<0.05$ - mean values $(\mathrm{n}=3)$ denoted by the same letter in columns indicate no significant difference according to Duncan's test

Table 4. Cadmium tolerance index of shoots and roots radish plant growing in sandy soil as exposed to different $\mathrm{Cd}$ concentrations

\begin{tabular}{|c|c|c|c|c|c|}
\hline \multirow[b]{2}{*}{ Compost } & \multirow{2}{*}{$\begin{array}{c}\text { Cd concentration } \\
\left(\mathrm{mg}^{\mathrm{k}} \mathrm{kg}^{-1}\right)\end{array}$} & \multicolumn{2}{|r|}{ Shoot } & \multicolumn{2}{|r|}{ Root } \\
\hline & & $\begin{array}{l}\text { Dry weight } \\
\left.\text { (g.plant }{ }^{-1}\right)\end{array}$ & $\begin{array}{c}\text { Cd tolerance index } \\
(\%)\end{array}$ & $\begin{array}{l}\text { Dry weight } \\
\left(\text { g.plant }{ }^{-1}\right)\end{array}$ & $\begin{array}{c}\text { Cd tolerance index } \\
(\%)\end{array}$ \\
\hline \multirow{4}{*}{ Zero } & 0 (control) & $0.55 \mathrm{a}$ & 100 & $0.22 \mathrm{a}$ & 100 \\
\hline & 40 & $0.51 \mathrm{a}$ & 92.7 & $0.18 \mathrm{ab}$ & 81.8 \\
\hline & 80 & $0.40 \mathrm{bc}$ & 72.7 & $0.15 \mathrm{ab}$ & 68.2 \\
\hline & 160 & $0.36 \mathrm{bc}$ & 65.5 & $0.12 \mathrm{abc}$ & 54.5 \\
\hline \multirow{4}{*}{ Low } & 0 (control) & $0.74 \mathrm{a}$ & 100 & $0.29 \mathrm{a}$ & 100 \\
\hline & 40 & $0.65 b$ & 87.8 & $0.22 \mathrm{a}$ & 76.0 \\
\hline & 80 & $0.57 \mathrm{c}$ & 77.0 & $0.18 \mathrm{ab}$ & 62.1 \\
\hline & 160 & $0.54 \mathrm{c}$ & 73.0 & $0.13 \mathrm{ab}$ & 44.8 \\
\hline \multirow{4}{*}{ High } & 0 (control) & $1.31 \mathrm{a}$ & 100 & $0.47 \mathrm{a}$ & 100 \\
\hline & 40 & $1.10 \mathrm{ab}$ & 84.0 & $0.39 \mathrm{~b}$ & 83.0 \\
\hline & 80 & $0.98 \mathrm{ab}$ & 74.8 & $0.29 \mathrm{c}$ & 61.7 \\
\hline & 160 & $0.80 \mathrm{c}$ & 61.1 & $0.19 \mathrm{~d}$ & 40.4 \\
\hline
\end{tabular}

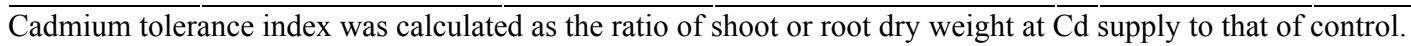

$\mathrm{p}<0.05$ - mean values $(\mathrm{n}=3)$ denoted by the same letter in columns indicate no significant difference according to Duncan's test 

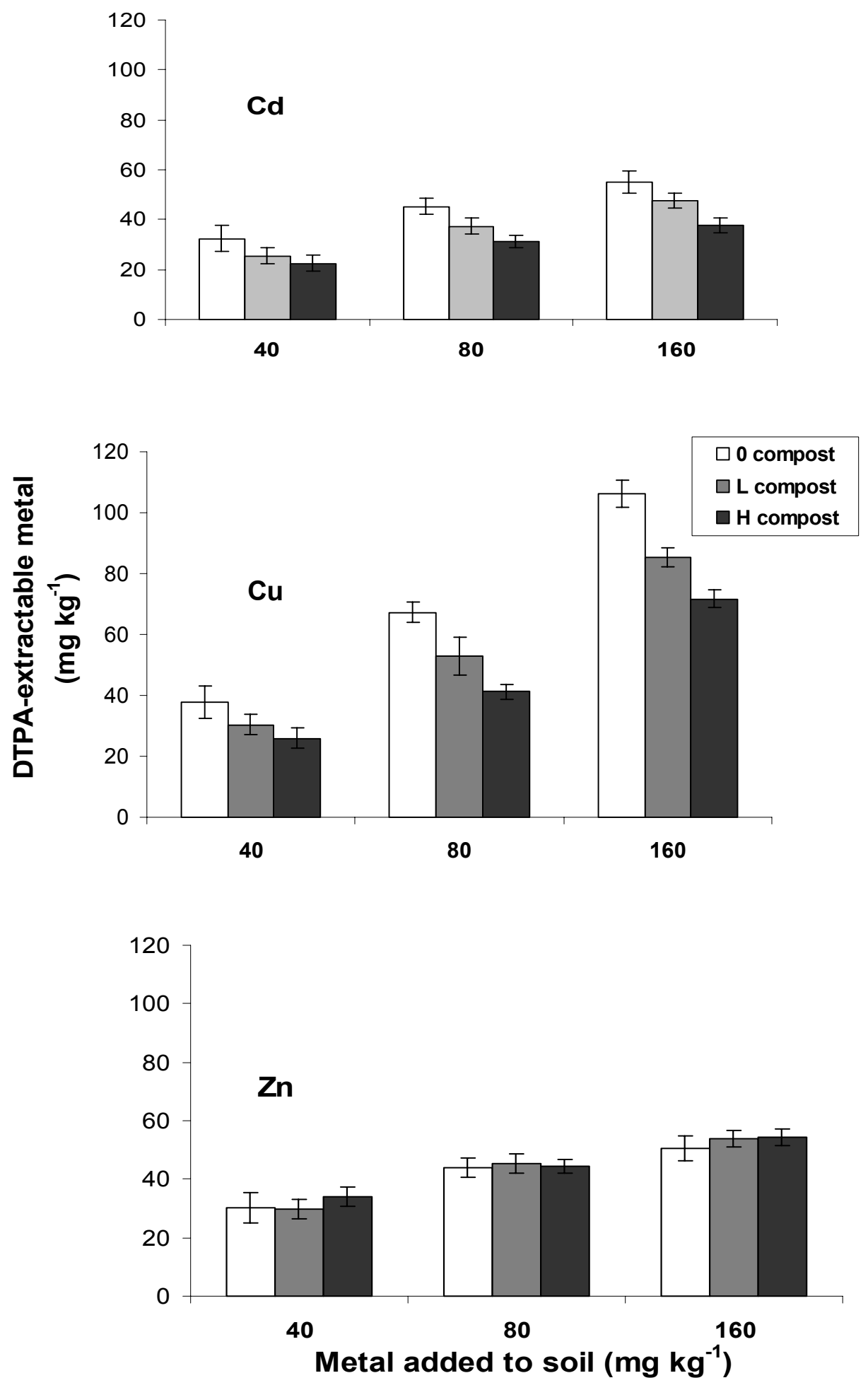

Fig. 1. Effect of different levels of compost on DTPA metals extractability in sandy soil. L. Low; H. High. Error bars correspond to standard deviations calculated with triplicates 

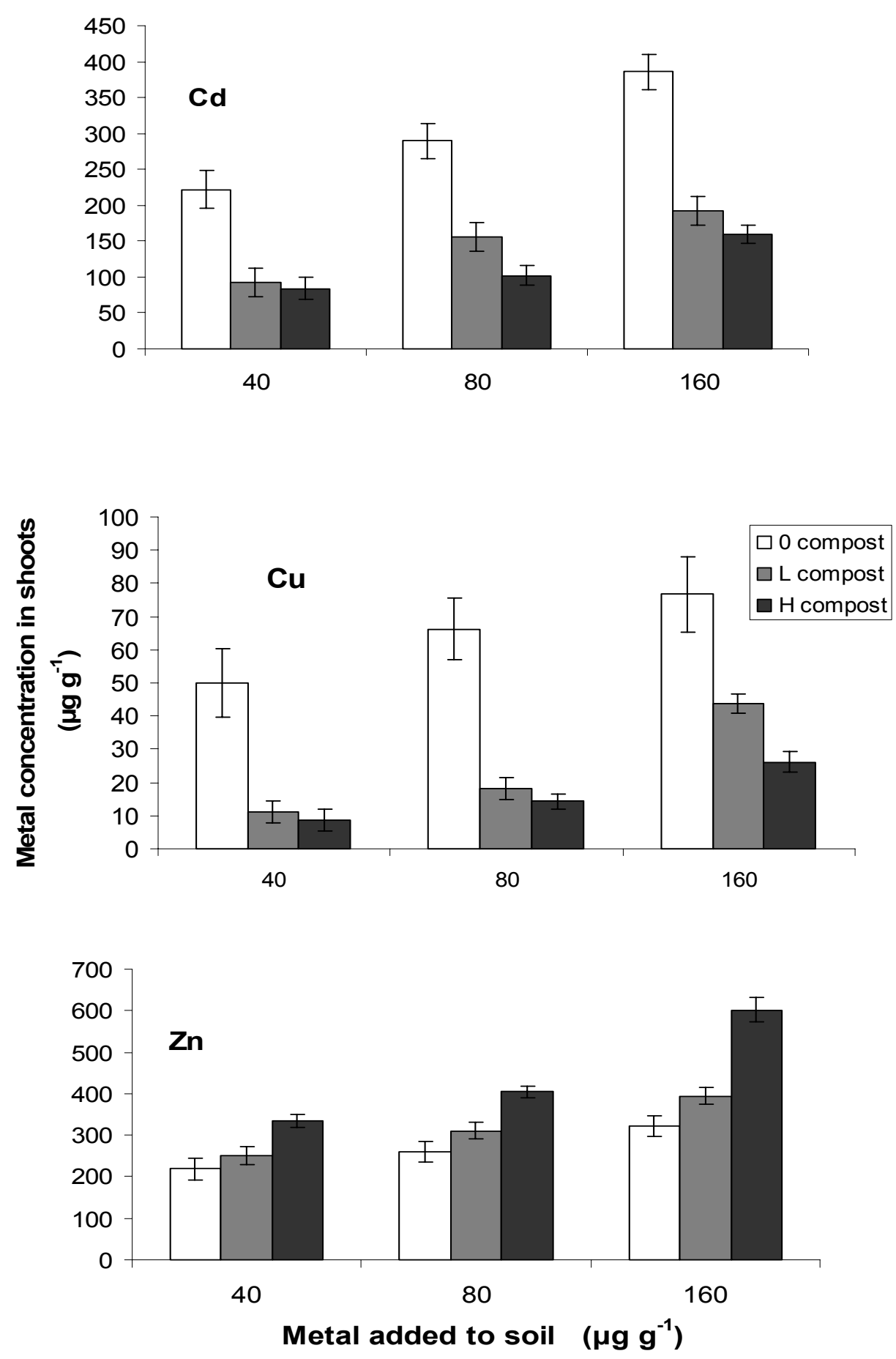

Fig. 2. Metal concentrations in radish shoots grown in sandy soil amended with different levels of compost. L. Low; H. High. Error bars correspond to standard deviations calculated with triplicates 

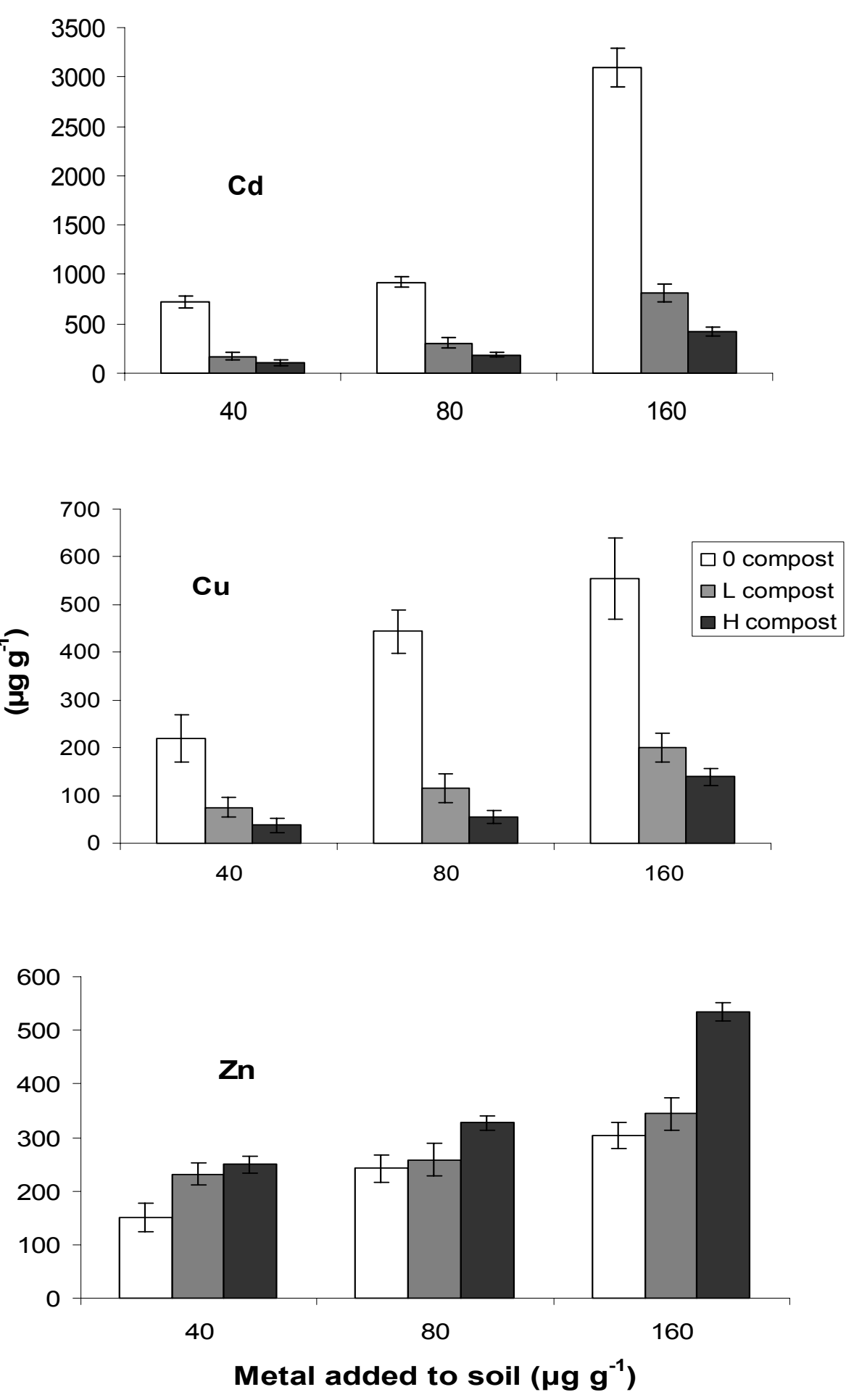

Fig 3. Metal concentrations in radish roots grown in sandy soil amended with different levels of compost. L. Low; H. High. Error bars correspond to standard deviations calculated with triplicates 

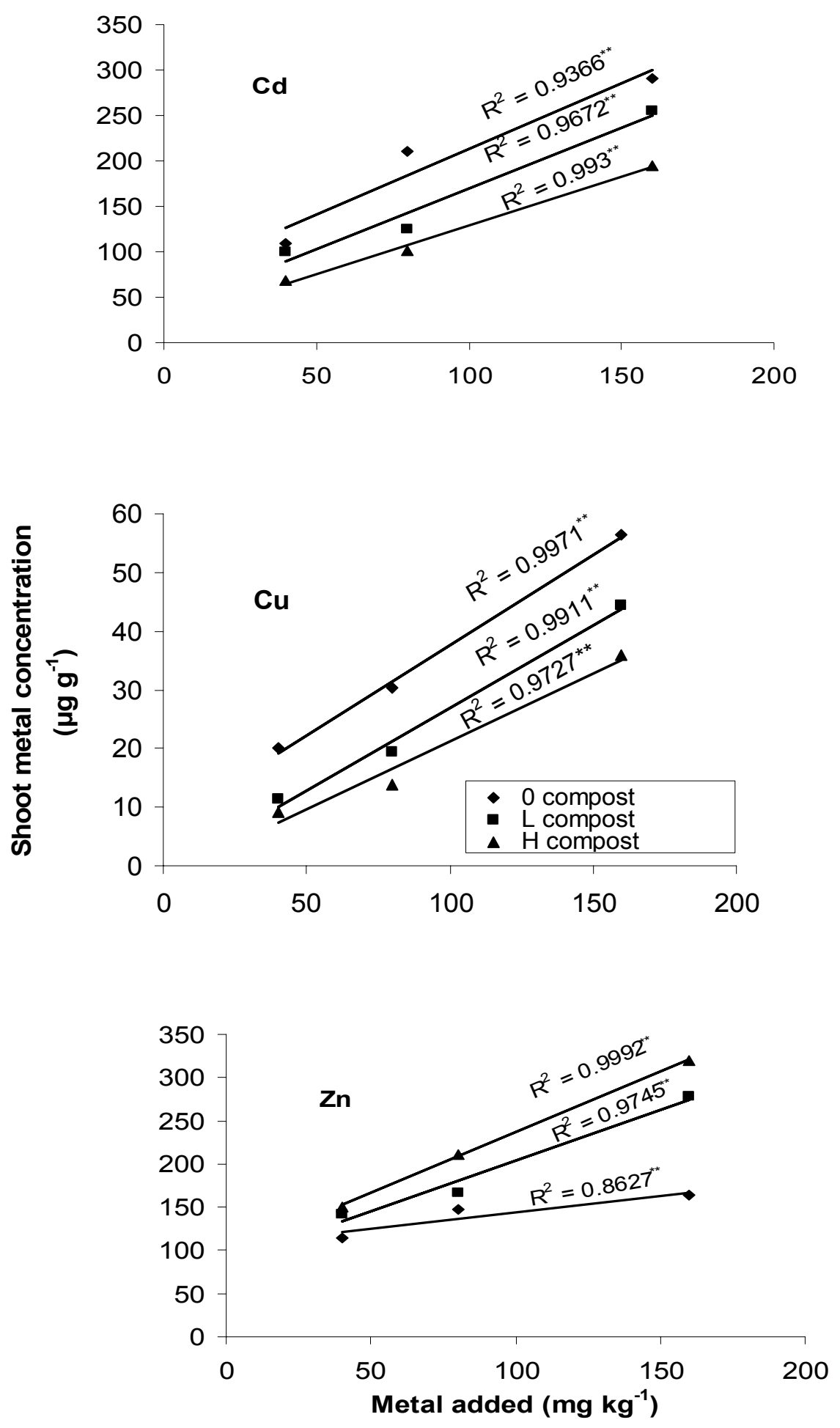

Fig. 4. Relationship between amount of element added to the soil and absorbed amount into shoots radish plant grown in calcareous soil amended with different levels of compost. $L$. Low; H. High. *, **: significant at 0.05 and 0.01 probability levels, respectively 

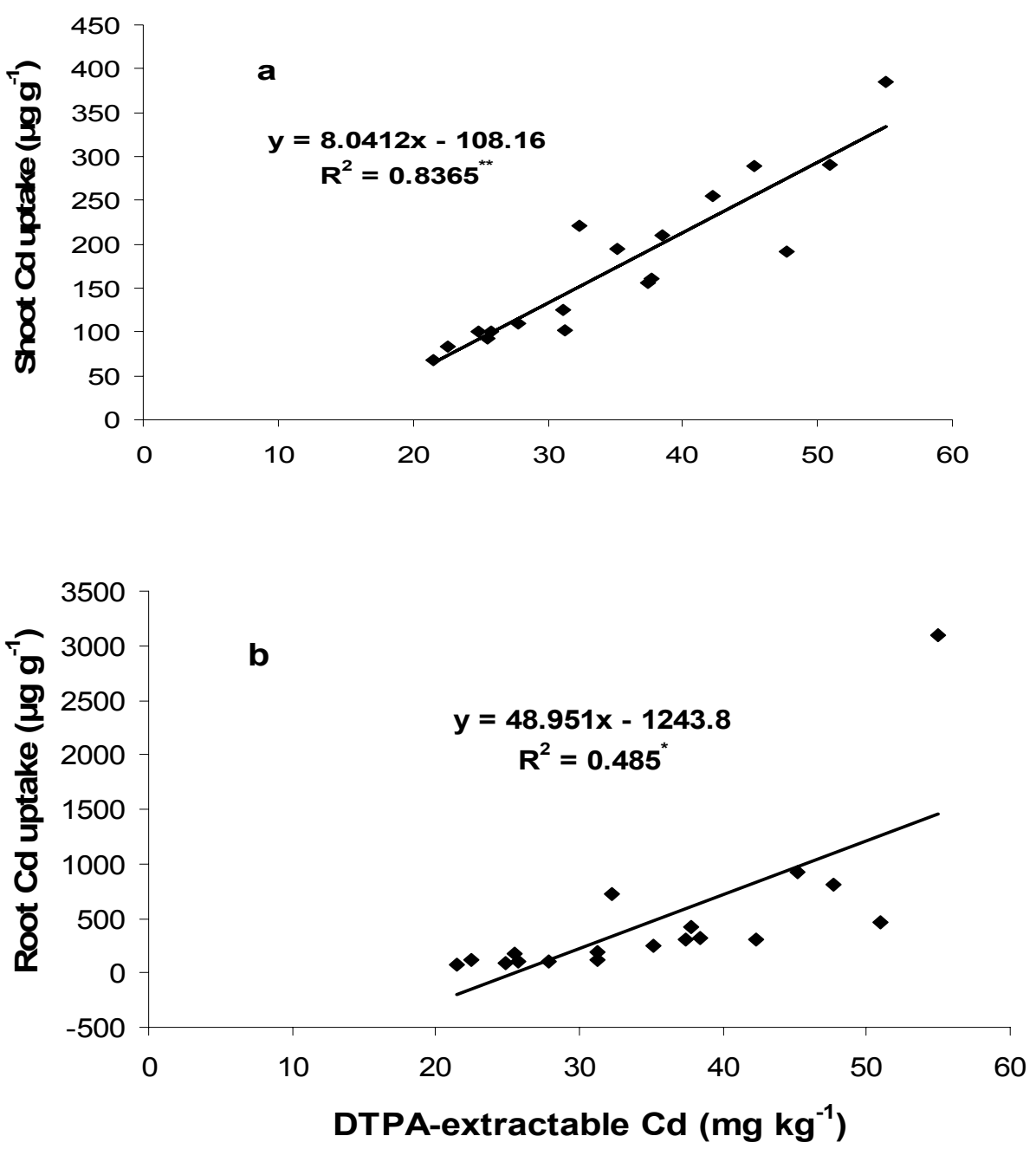

Fig. 5. Relationship between Cd extracted by DTPA and Cd uptake into shoots or roots of radish plant grown in calcareous and sandy soils amended with different levels of compost. *, **: significant at 0.05 and 0.01 probability levels, respectively

These results coincide with and validate the data obtained from the DTPA extraction experiments. For instance, the concentrations of $\mathrm{Cd}$ in shoot at $80 \mathrm{mg} \mathrm{kg}^{-1}$ soil amended with low compost rate was decreased to 40.36 and $46.27 \%$ for calcareous and sandy soils, respectively comparing to corresponding each control treatment ( 0 , compost addition); while high compost rate decreased $\mathrm{Cd}$ concentration to 52.13 and $64.63 \%$ for calcareous and sandy soils, respectively. At the same contaminated rate, root $\mathrm{Cd}$ concentration was decreased to 62.39 and $66.62 \%$ due to addition of low compost rate and to 65.57 and $79.89 \%$ as high compost addition for calcareous and sandy soils, respectively. Similar results were obtained regarding $\mathrm{Cu}$ for both shoots and roots. On the other side, addition of low compost amendment increased $\mathrm{Zn}$ concentration at $80 \mathrm{mg} \mathrm{kg}^{-1}$ soils to 13.67 and $27.86 \%$ in calcareous soil and to 19.07 and $6.87 \%$ in sandy soil for shoot and root of each soil, respectively. The high compost rate also, at $80 \mathrm{mg} \mathrm{kg}^{-1}$ soils, increased $\mathrm{Zn}$ concentration in calcareous soil to 43.60 and $34.72 \%$ for shoot and root, respectively; whereas this increase in sandy soil was 55.57 and $35.31 \%$ for shoot and root, respectively.

Thus, these findings showed that the addition of the compost amendment simultaneously reduced the bioavailability of $\mathrm{Cd}$ and $\mathrm{Cu}$ and increased $\mathrm{Zn}$ bioavailability which highlights the applicable of using compost to immobilize $\mathrm{Cd}$ and $\mathrm{Cu}$ in high contaminated soils. Similarity to the current results, Tordoff et al. (2000) demonstrated that organic amendments such as mature compost, which contain a high proportion of humified OM, can decrease the bioavailability of heavy 
metals in soil, thus permitting the re-establishment of vegetation on contaminated sites.

The correlation between total $\mathrm{Cd}, \mathrm{Cu}$, and $\mathrm{Zn}$ accumulation in shoot or root of radish plants grown in both soils in the presence and absence of compost amendments and these metals concentration in DTPA extracts was examined. The correlations are shown for $\mathrm{Cd}$ as examples in Fig. 5. In common, correlation coefficients $\left(\mathrm{R}^{2}\right)$ of metals accumulation in plants to metals concentration of DTPA soil extracts was significant in most cases with more pronounced in shoots than in roots. These $\mathrm{R}^{2}$ values were for $\mathrm{Cd}(0.84$, $0.49)$, for $\mathrm{Cu}(0.67,0.35)$, and for $\mathrm{Zn}(0.45,0.44)$ for shoots and roots, respectively. Significant values of $\mathrm{R}^{2}$ indicate that 84 and $67 \%$ of the decrease in $\mathrm{Cd}$ and $\mathrm{Cu}$, respectively and $45 \%$ of the increase in $\mathrm{Zn}$ in shoot radish plants correlated with the decrease $(\mathrm{Cd}$ and $\mathrm{Cu}$ case) or increase ( $\mathrm{Zn}$ case) of DTPA extracts resulting from compost amendment to the soils. Also, the same trend was obtained for roots treatments.

\section{CONCLUSION}

Compost application increased strongly the plant biomass for all cases even in high level of metals contaminated soil. This implied that the phytotoxicity of heavy metals is influenced by addition of compost amendment. Since plant yields could be used as an index of amelioration success. It is evident that addition of compost amendments could mitigate heavy metals phytotoxicity. The results obtained from DTPA extraction coupled with the greenhouse experiment and, furthermore, the high $\mathrm{R}^{2}$, in most cases, between extracted and absorbed metals validate the hypothesis that compost amendment can be applied in contaminated soils to reduce $\mathrm{Cd}$ and $\mathrm{Cu}$ bioavailability. However, the increase of $\mathrm{Zn}$ as a result of compost amendment may be useful in alkaline soil, such as studied soils, suffering from Zn low solubility.

\section{REFERENCES}

Ahumada, I., J. Mendozo, J. Ascar. 1999. sequential extraction of heavy metals in soil irrigated wastewater. Soil Sci. Plant Anal. 30:1507-1519.

Almas, A., B.R. Singh, and B. Salbu. 1999. Mobility of cadmium-109 and zinc in soil influenced by equilibrium time, temperature, and organic mater. J. Environ. Qual. 28:1742-1750.

Basta, N. T., R. Gradwohl, K. L. Snethen, and J. L. Schorden. 2001. Chemical immobilization of lead, zinc and cadmium in smelter contaminated soils using biosolids and rock phosphate. J. Environ. Qual. 30: 1222-1230.

Bohn, H. L., B. L. McNeal, and O. G. A. Connor. 1985. Soil Chemistry. $2^{\text {nd }}$ edition. Wiley, New York.

Cao, X., L. Q. Ma, D. R. Rhue, and C. S. Appel. 2004. Mechanisms of lead, copper, and zinc retention by phosphate rock. Environ. Pollut. 131:435-44.
Caravaca, F., D. Figueroa, M.M. Alguacil, and A. Roldan. 2003. Application of composted urban residue enhanced the performance of afforested shrub species in a degraded semiarid land. Biores. Technol. 90: 65-70.

Dahiya, S, A. V. Shanwal, and H. A. G. Hedge. 2005. Studies on the sorption and desorption characteristics of $\mathrm{Zn}$ (II) on the surface soils of nuclear power plants sites in India using a radiotracer technique. Chemosphere. 60: 12531261.

Drażkiewicz, M., A. Tukendorf, and T. Baszyński. 2003. Age dependent response of maize leaf segments to cadmium treatment: Effect on chlorophyll fluorescence and phytochelation accumulation. J. Plant Physiol. 160: 247254.

Dube, B.K., P. Sinha, R. Gopal, and C. Chatterjee. 2003. Modulation of radish metabolism by zinc phytotoxicity. Ind. J. Plant Physiol. 8: 302-306.

Esakku, S., A. Selvam, J. Kurian, and K. Palanivelu .2005. Assessment of heavy metal species in decomposed municipal solid waste. Chem. Spec. Bioavailab. 17:95102.

Finžgar, N., B. Kos, and D. Leštan. 2006. Bioavailability and Mobility of $\mathrm{Pb}$ after soil treatment with different remediation methods. Plant, Soil and Environ. 52: 25-34.

Florijn, P. J., and M. L. Van Beusichem. 1993. Uptake and distribution of cadmium in maize inbred lines. Plant Soil 150:25-32.

Hashimoto, Y., H. Matsufuru, M. Takaoka, H. Tanida, and T. Sato. 2009. Impacts of chemical amendment and plant growth on lead speciation and enzyme activities in a shooting range soil: An x-ray absorption fine structure investigation. J. Environ. Qual. 38:1420-1428.

Hillel, D., V.D. Krentos, and Y. Stylianov. 1972. Procedure and test of an internal drainage method for measuring soil hydraulic characteristic in situ. Soil Sci. 114:395-400.

Karlsson, T., P. Persson, and U. Skyllberg. 2006. Complexation of copper (II) in organic soils and in dissolved organic matter: EXAFS evidence for chelate ring structures. Environ. Sci. Technol. 40: 2623-2628.

Kaschl, A., V. Romheld, and Y. Chen. 2002. Cadmium Binding by Fractions of Dissolved Organic Matter and Humic Substances. J. Environ. Qual. 31:1885-1892.

Keeney, D.R. and D.W. Nelson. 1982. Nitrogen-inorganic forms, in: A.L. Page (Ed.), Methods of Soil Analysis. Part 2. Chemical and microbiological properties, Am. Soc. Agron., Madison, pp. 643-698.

Kuo, S. P, E. Heilman, and A. S. Baker. 1983. Distribution and forms of copper, zinc, cadmium, iron, and manganese in soils near a copper smelter. Soil Sci. 135:101-109.

Lindsay. W.L. and W.A. Norvell. 1978. Development of a DTPA soil test for zinc, iron, manganese, and copper. Soil Sci. Soc. Amer. J. 42:421-428.

Manivasagaperumal, R., S. Balamurugan, G. Thiyagarajan, and J. Sekar. 2011. Effect of Zinc on Germination, Seedling Growth and Biochemical Content of Cluster Bean (Cyamopsis tetragonoloba (L.) Taub). Curr. Bot. 2: 11-15. 
McBride, M. B. 1994. Environmental Chemistry of Soils. Oxford University Press, New York. S592.5.M39 631.4'Idc20 93-1552

Meers, E., G. Laing Du, V. Unamuno, A. Ruttens, J. Vangronsfeld, F.M.G. Tack, and M.G. Verloo. 2007. Comparison of cadmium extractability from soils by commonly used single extraction protocols. Geoderma 141: 247- 259 .

Moharem, M. L. 2008. Mobility and Bioavailability of Heavy Metals in Soils: Effect of Dissolved Organic Carbon. Ph. D. Thesis, Fac. of Agric. Alex. Univ. Egypt.

Moharem, M. L. 2016. Solubility and availability of heavy metals in soils as affected by compost amendment. Alex. Sci. Exch. J. 37:36-44.

Murthy, A. S. P. and H. G. A. Schoen. 1987. A comparative study of the soil zinc fractions determined by chemical methods and electro-ultrafiltration (EU) and their relations to zinc nutrition in rice. Plant Soil 102: 207-210.

Narwal, R.P. and B.R. Singh. 1998. Effect of organic materials on partitioning, extractability and plant uptake of metals in an alum shale soil. Water Air Soil Pollut. 103: 405-421.

Nelson, D.W. and L.E. Sommers. 1982. Total carbon, organic carbon and organic matter. In: Page A.L., Miller R.H., Keeney D.R. (eds) Methods of Soil Analysis. Am. Soc. Agron.,Madison,Wisconsin, USA, pp 539-549

Nelson, R.E. 1982. Carbonate and gypsum. In: Page AL, Miller RH, Keeney DR (eds) Methods of Soil Analysis. Am. Soc. Agron, Madison, pp 181-197.

Ouariti, O., H. Gouia, and M.H. Ghorbel. 1997. Responses of bean and tomato plants to cadmium: Growth, mineral nutrition and nitrate reduction. Plant Physiol. Biochem.35: 347-354.

Peijnenburg, W.J.G.M., M. Zablotskaja, and M.G. Vijver. 2007. Monitoring metals in terrestrial environments within a bioavailability framework and a focus on soil extraction. Ecotox. and Environ. Safety 67: 163-179.

Perez-de-Mora, A., F. Madrid, F. Cabrera, and E. Madejon. 2007. Amendments and plant cover influence on trace element pools in a contaminated soil. Geoderma 139: 110 .

Ponizovsky, A., H. E. Allen, and A. J. Ackerman. 2007. Copper activity in soil solutions of calcareous soils. Environ. Pollut. 145: 1-6.

Ramos, L., L. M. Hernandez, and M. J. Gonzales. 1994. Sequential fractionation of copper, lead, cadmium and zinc in soils from Do nana National Park. J. Environ. Qual. 23:50-57.
Rauser, W. E. 1986: The amount of cadmium associated with Cd-binding protein in roots of Agrostis gigantea, maize and tomato. Plant Sci. 43: 85-91.

Reichman, S.M. 2002. The Responses of Plants to Metal Toxicity: A review focusing on Copper, Manganese and Zinc. Australian Minerals \& Energy Environment Foundation. Published as Occasional Paper No.14 .ISBN 1-876205-13-X.

Ren, L. M, P. Liu, and Q. E. Zheng. 2006. A survey of heavy metal content of plants growing on the soil polluted by manganese mine in Daxin County, Guangxi. Subtrop. Plant Sci. 35: 5-8.

Rhoades, J. D. 1982. Cation exchange capacity. In: Page A.L. (ed.) Methods of soil analysis. Part 2: Chemical and microbiological properties (2nd ed.) Agron. 9:149-157.

Richards, L.A. 1954. Dignosis and improvement of alkaline soils. USDA Handbook 60. US Government Printing Office, Washington, DC, USA, p 152

Sanchez, M. M., C. Mondini, M. Nobili, L. Leita, and A. Roig. 2004. Land application of biosolids: Soil response to different stabilization degree of the treated organic matter. Waste Manag. 24: 325-332.

Tessier, A., P. G. C. Campbell, and M. Bisson. 1980. Trace metal speciation in the Yamaoka and St. Francois Rivers (Quebec). Can. J. Earth Sci. 17:90-105.

Tordoff, G.M., A.J.M. Baker, and A.J. Willis. 2000. Current approaches to the re-vegetation and reclamation of metalliferous mine wastes. Chemosphere 41: 219-228.

United States Environmental Protection Agency. 1999. "Solidification/Stabilization Resource Guide," Office of Solid Waste and Emergency Response (5102G), www.epa.gov, cluin.org

Ure, A.M. 1995. Methods of soil analysis for heavy metals in soils. In: Alloway BJ (ed) Heavy metals in soils, $2^{\text {nd }}$ edn. Blackie Academic and Professional, London, pp 58-95.

Van Herwijnen, R., T. Hutchings, A. Al-Tabbaa, A.J. Moffat, M.L. Johns, and S.K. Ouki. 2007. Remediation of metal contaminated soil with mineral-amended composts. Environ. Pollut. 150, 347-354.

Wang, Q. R, Y. S. Cui, X. M. Liu, Y. T. Dong, and P. Christrie. 2003. Soil contamination and plant uptake of heavy metals at polluted sites in china. J. Environ. Sci. Health. 38:823-838.

Wang, Q.L., L. Luo, Y.B., D.P. Ma Wei, and L. Hua. 2009. In situ immobilization remediation of heavy metalscontaminated soils: A review. Chinese J. Appl. Ecol. 20:1214-1222.

Ye, Z.H, J.W.C. Wong, M.H. Wong, C.Y. Lan, and A.J.M. Baker. 1999. Lime and pig manure as ameliorants for the revegetation on lead/zinc mine tailings: A greenhouse study. Biores. Technol. 69: 35-45. 


\section{الملغص العري \\ صلاحية وإمتصاd نبلت الفبل لعناهر الكالميو، النحس والزك في الأراضي الملوثة تنه تنأثير معالات الكمبوست}

محمد لطفي محرم ، هالي لحمد صلاح متولي ، محمد رشاد، للسيشلبى، لحمد مرسي

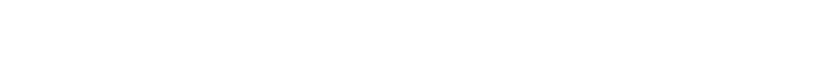
إنخفاض الوزن الجل لنبلت الفبل.

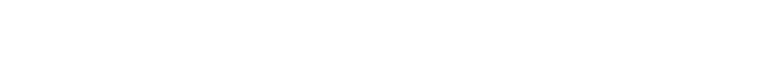
المستوي المنخفض إلي المستوي العالي إلي إنخفاض كلا

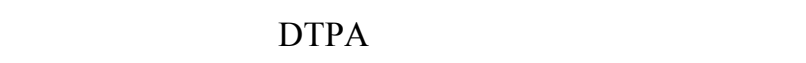
والكاميوم وتركيز هذه العناصر في جذور وسيقلن نبلت الفجل؛ بينماسلك عنصر الزيكسلوكاً عكسياً

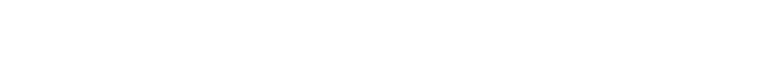

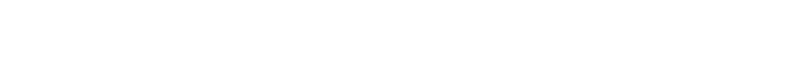

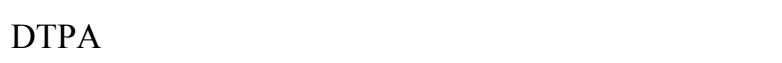
معنويا. القيمة المعنوية لمعالل الأرتبط دلت علي أن الإنغفاض

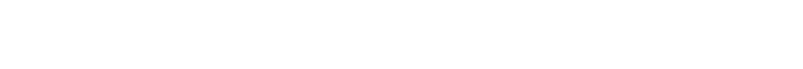
بالإنخفاض الحادث في كمية الكاميوم والنطلس المستخلص في فئل من الأراضي بل DTPA والنالتج من إضافة الكمبوست إلي لإني

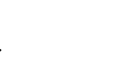

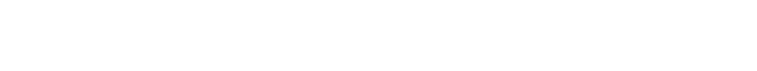

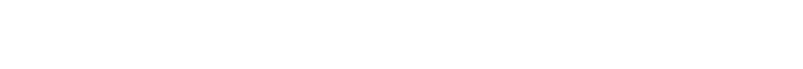

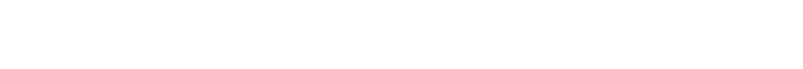

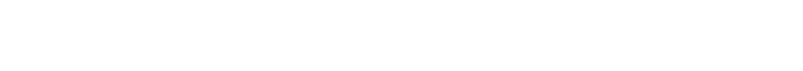

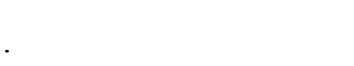

لجريت هذه الدرلمة في الصوبة الزراعية لقييم تأثير

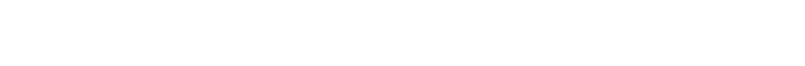

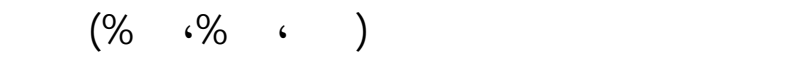
لُٔسلس الوزن علي كل من الإتلحة الحيوية بأستخدلم مستخلص DTPA وعلي إمتصاص نبلت الفبل لعناصر

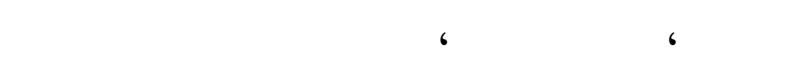

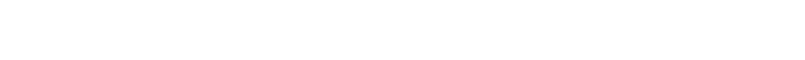
وتجارب الزراعة الفعلية. ولتحقيق هذا الهذف مُ إجراء

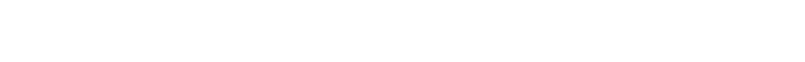

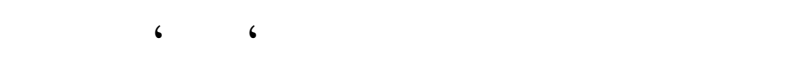

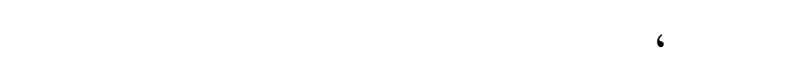

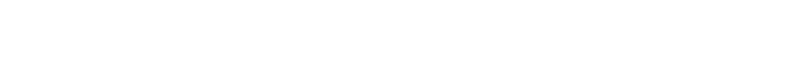

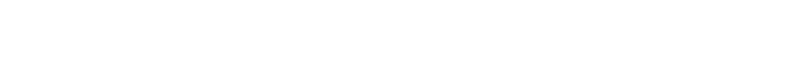
سيقان وجذور نبلت الفبل للعناصر مطل الدرلمة و كذك الك المبل أثرها علي الوزن الجلف لنبت الفبل تهت هذه المستويت المختلفةساقة النكر.

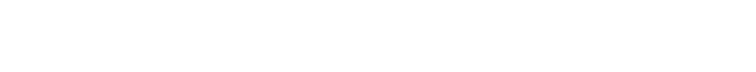
سواء الملوثة أوالغير ملوثة بالعناصر أدي إلي زيالة معنوية المانية

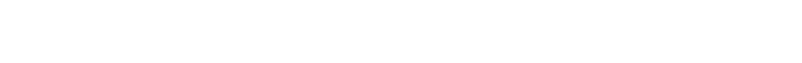

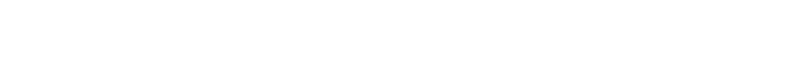
كجم تربة أدي إلي زياة الوزن الجلف لنبت الفجل بينما 